\title{
Mechanical Properties of Moringa (Moringa oleifera) Seeds in relation to an Oil Expeller Design
}

\author{
AJAV, Emmanuel Atoo ${ }^{1}$ and FAKAYODE, Olugbenga Abiola ${ }^{2}$ \\ ${ }^{1}$ Department of Agricultural and Environmental Engineering, University of Ibadan, NIGERIA. \\ ${ }^{2}$ Department of Agricultural and Food Engineering, University of Uyo, NIGERIA. \\ Corresponding author: eaajav@yahoo.co.uk, +234 8023305155.
}

\begin{abstract}
Mechanical properties are very important in the design of machines and the analysis of the behaviour of products during agricultural processing. In this research work, the mechanical properties of Moringa were determined as design parameters for the development of an oil expeller for the crop. The properties were the applied force, deformation, stress, energy and Young Modulus. They were determined at peak, break and yield.The average force at peak, deformation at peak, stress at peak and energy to peak were found to be $58.535 \mathrm{~N}, 5.0990 \mathrm{~mm}$, $49.26 \mathrm{~N} / \mathrm{mm}^{2}$ and $0.1344 \mathrm{~N} . \mathrm{m}$ respectively. The average force at break, deformation at break, stress at break and energy to break were found to be $58.420 \mathrm{~N}, 5.1241 \mathrm{~mm}, 49.12 \mathrm{~N} / \mathrm{mm}^{2}$ and 0.1357 N.m respectively. The force at yield, stress at yield and energy to yield were found to be $39.000 \mathrm{~N}, 33.66 \mathrm{~N} / \mathrm{mm}^{2}$ and $0.0224 \mathrm{~N} . \mathrm{m}$ respectively. The Young's modulus was found to be $195.32 \mathrm{~N} / \mathrm{mm}^{2}$. These parameters would provide important and essential data for the efficient design of the oil expeller.
\end{abstract}

Keywords: Moringa, Mechanical Properties, Oil, Oil Expeller.

\section{INTRODUCTION}

Oilseeds are important components of tropical agriculture as they provide readily available and highly nutritious human and animal foods. Nigeria is blessed with many varieties of oilseeds grown over the country that the oil and fat industry could be an important industrial sector if the oilseeds are properly harnessed and utilized. The vegetable oil industry could contribute significantly to further industrialization in Nigeria and satisfy our needs for edible oils and fats, animal feed and industrial raw materials for the manufacturing of soap, paints, detergents, candles, lubricants, linoleum, printing ink, vanishes, polymers and some pharmaceutical products (Olajide, 2000). At present, this is not being achieved because most of the locally available oilseeds that can be used for the provision of edible and industrial oils are un-exploited or greatly under-exploited. Those oilseeds that are exploited are processed using crude technologies that are wasteful and produce low quality oils and cakes (Ajibola, 2000). Five common methods of extracting oil have been identified. These are: water assisted (finely ground oilseed is either boiled in water and the oil that floats on the surface is skimmed off; or ground kernels are mixed with water, squeezed and mixed 
by hand to release the oil); manual pressing (oilseeds, usually pre-ground, are pressed in manual screw presses); expelling (using an expeller which consists of a motor driven screw turning in a perforated cage; the screw pushes the material against a small outlet, the "choke"; great pressure is exerted on the oilseed fed through the machine to extract the oil); ghanis (consisting of a large pestle and mortar rotated either by animal power or by a motor; seed is fed slowly into the mortar and the pressure exerted by the pestle breaks the cells and releases the oil); and solvent extraction (where oil from seeds or the cake remaining from expelling is extracted with solvents and the oil is recovered after distilling off the solvent under vacuum). Oil bearing crops are subjected to mechanical forces during oil extraction/expression process. These forces frequently result to deformation of the crops. Thus, the mechanical strength of the crops plays an important role in the oil extraction/expression process. Most agricultural products are visco-elastic in nature; they respond differently to tensile or compressive forces and also behave differently when they are subjected to vibration. Therefore, a fundamental knowledge of agricultural product behaviour under mechanical forces is essential in determining the power requirement for different operations (Ozumba and Obiakor, 2011). A rational approach to the design of agricultural machinery, equipment and facilities involves the knowledge of the engineering properties of the agricultural product concerned. Considering this, the knowledge of the mechanical properties (properties that have to do with the behaviour of agricultural products under applied forces) such as stress, strain, hardness and compressive strength is vital to engineers handling agricultural products (Chukwu and Sunmonu, 2010). Several researchers have investigated the mechanical properties of some oil bearing crops considered relevant to the design of suitable machines and equipment for their production and processing; but a review of literature showed little information on the mechanical properties of Moringa seeds, most especially, in relation to the design of an oil expeller. The objective of this study was to determine the mechanical properties of Moringa seeds in relation to the design of an oil expeller.

\section{MATERIALS AND METHODS}

Mechanical properties of Moringa seeds namely crushing force, deformation and rupture energy were evaluated as design parameters for the development of an oil expeller for the crop. They were determined following standard procedures. Instron Universal Testing Machine equipped with a $25 \mathrm{~kg}$ compression load cell and integrator was used to determine various mechanical properties of the seeds namely: force at peak, deformation at peak, stress at peak, energy to peak, force at break, deformation at break, stress at break, energy to break, force at yield, stress at yield, energy to yield and the Young's Modulus. The measurement accuracy was $0.001 \mathrm{~N}$ in force and $0.001 \mathrm{~mm}$ in deformation (Mohsenin, 1970). The height of the seed when loaded in the machine was noted. The individual seed was compressed by the machine until rupture occurred as is denoted by a bio-yield point in the force-deformation curve. The rupture point is a point on the force-deformation curve at which the loaded specimen shows a visible or invisible failure in the form of breaks or cracks. This point was detected by a continuous decrease of the load in 
the force-deformation diagram. Once the bio-yield was detected, the loading was stopped. The various parameters were measured at a speed of $20 \mathrm{~mm} / \mathrm{min}$ and an average moisture content of $7.31 \%$ wet basis for twenty randomly selected Moringa seeds.

\section{RESULTS AND DISCUSSION}

A summary of the results of the mechanical properties of Moringa seeds measured is presented in Table 1. The force-deformation/deflection curves are shown in Figures 1and 2, while Figures 3 and 4 show the force-strain curves for the samples tested. The force-deformation curves obtained in this investigation were similar to those obtained by previous researchers on different oil bearing crops viz: Ozumba and Obiakor (2011) on Palm-kernel seed, Manuwa and Muhammad (2010) on Shea kernel and Bamgboye and Adejumo (2011) on Roselle seeds; amongst others. The average force to rupture the seed was obtained as $58.535 \mathrm{~N}$ varying from $49.900 \mathrm{~N}$ to $67.000 \mathrm{~N}$; while the average rupture energy of the seed was found to be $0.1344 \mathrm{~N} . \mathrm{m}$ ranging from $0.1043 \mathrm{~N} . \mathrm{m}$ to $0.1708 \mathrm{~N} . \mathrm{m}$. The average deformation was $5.0990 \mathrm{~mm}$ varying from $4.8500 \mathrm{~mm}$ to $5.3540 \mathrm{~mm}$. Maximum strains of about $85 \%$ was recorded for the Moringa seeds. The applied force will be used in the calculation of the main forces acting on the screw of the expeller. 
Ajav and Fakayode

Table 1: Mechanical Properties of Moringa Seeds

\begin{tabular}{|c|c|c|c|c|c|c|c|}
\hline Physical Properties & $\begin{array}{l}\text { No of } \\
\text { observations }\end{array}$ & Unit & $\begin{array}{l}\text { Minimum } \\
\text { Value }\end{array}$ & $\begin{array}{l}\text { Maximum } \\
\text { Value }\end{array}$ & $\begin{array}{l}\text { Mean } \\
\text { Value }\end{array}$ & $\begin{array}{l}\text { Standard } \\
\text { Deviation }\end{array}$ & $\begin{array}{l}\text { Coefficient } \\
\text { of Variation }\end{array}$ \\
\hline Height of Loading & 20 & $\mathrm{~mm}$ & 4.17 & 7.73 & 6.80 & 0.969 & 14.25 \\
\hline Force at Peak & 20 & N & 48.900 & 67.000 & 58.535 & 5.472 & 9.35 \\
\hline Deformation at Peak & 20 & $\mathrm{~mm}$ & 4.8500 & 5.3540 & 5.0990 & 0.097 & 1.90 \\
\hline Stress at Peak & 20 & $\mathrm{~N} / \mathrm{mm}^{2}$ & 42.500 & 55.800 & 49.260 & 4.403 & 8.94 \\
\hline Energy to Peak & 20 & N.m & 0.1043 & 0.1708 & 0.1344 & 0.019 & 14.14 \\
\hline Force at Break & 20 & N & 48.900 & 67.000 & 58.420 & 5.479 & 9.38 \\
\hline Deformation at Break & 20 & $\mathrm{~mm}$ & 5.0530 & 5.3540 & 5.1241 & 0.078 & 1.52 \\
\hline Stress at Break & 20 & $\mathrm{~N} / \mathrm{mm}^{2}$ & 42.500 & 55.800 & 49.120 & 4.412 & 8.98 \\
\hline Energy to Break & 20 & N.m & 0.1056 & 0.1708 & 0.1357 & 0.018 & 13.26 \\
\hline Force at Yield & 20 & N & 19.800 & 54.300 & 39.000 & 7.170 & 18.38 \\
\hline Stress at Yield & 20 & $\mathrm{~N} / \mathrm{mm}^{2}$ & 27.300 & 38.900 & 33.660 & 4.011 & 11.92 \\
\hline Energy to Yield & 20 & N.m & 0.0277 & 0.1215 & 0.0584 & 0.022 & 37.67 \\
\hline- & 20 & $\mathrm{~N} / \mathrm{mm}^{2}$ & 66.65 & 147.95 & 195.32 & 17.850 & 9.14 \\
\hline
\end{tabular}


Ajav and Fakayode



Figure 1: Force-Deflection/Deformation Graph for Moringa seeds under Compressive loading. 


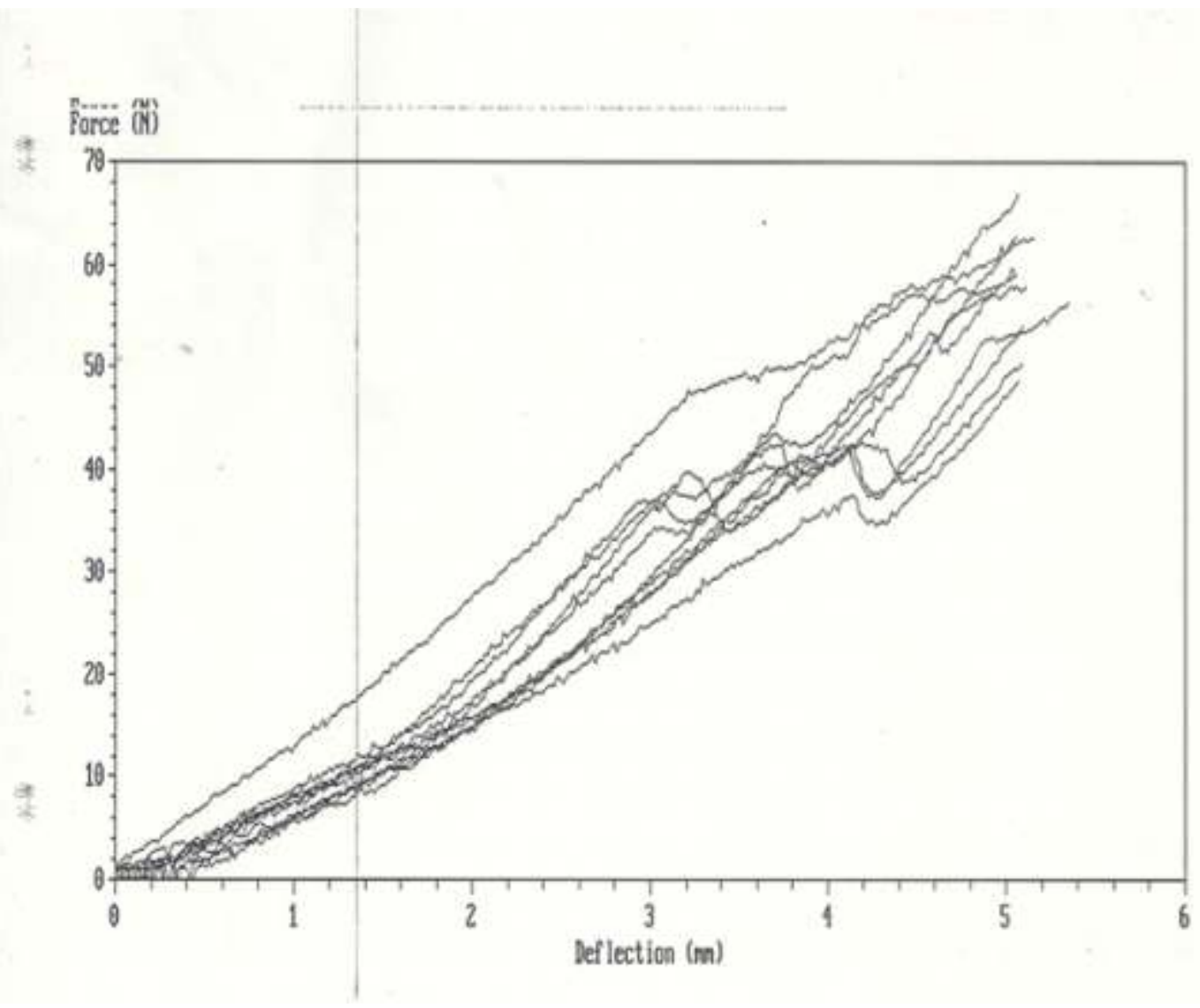

Figure 2: Force-Deflection/Deformation Graph for Moringa seeds under Compressive loading. 


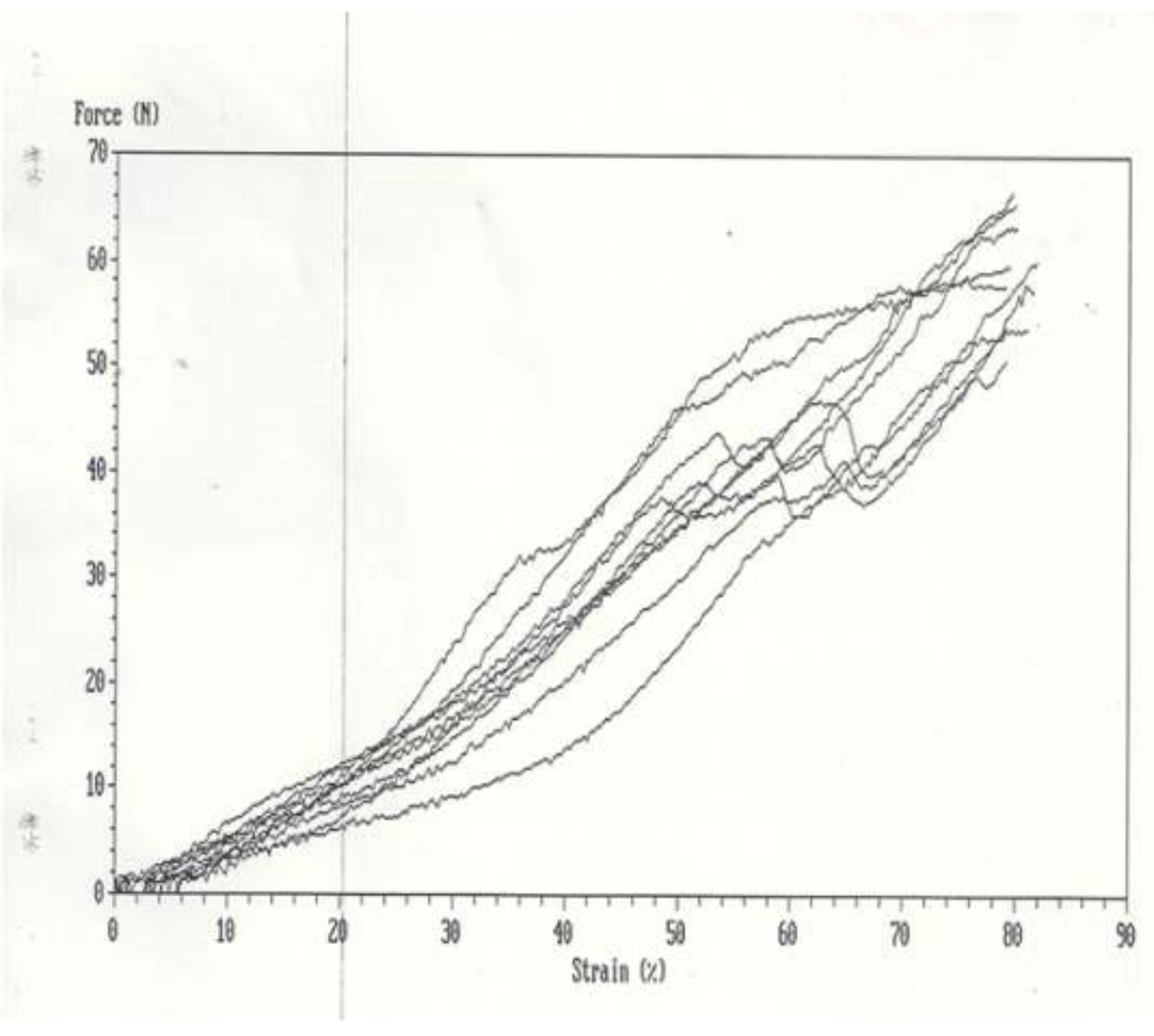

Figure 3: Force-Strain Graph for Moringa seeds under Compressive loading. 
Ajav and Fakayode

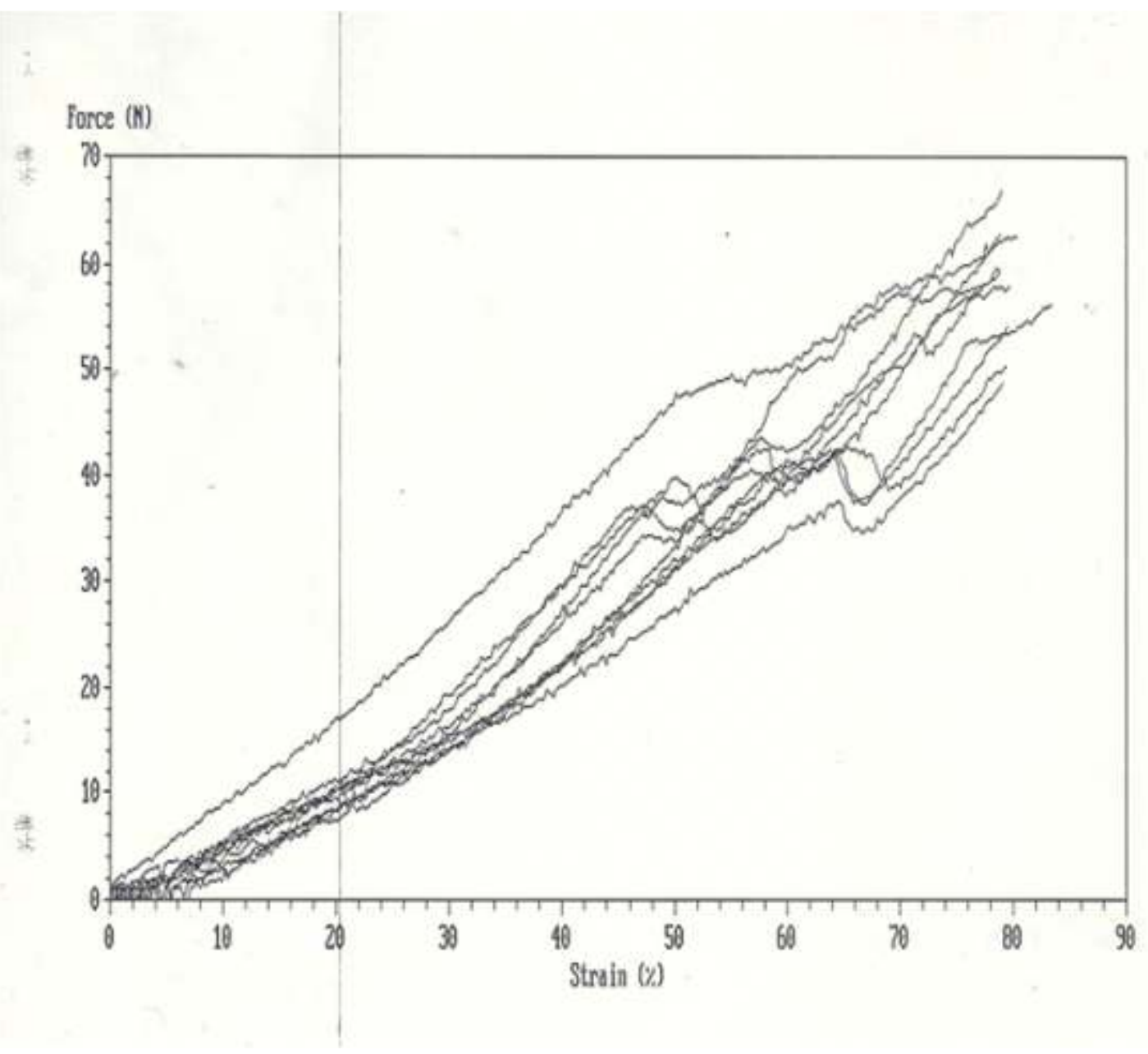

Figure 4: Force-Strain Graph for Moringa seeds under Compressive loading.

The bio-yield point in the force-deformation curves indicates the seed rupture point and this point was determined by a visual decrease in force as deformation increased. This point reflects the sensitivity of the Moringa seeds to damage. The rupture point indicates failure over a significant volume of the material. Beyond the rupture point, the stress decreases rapidly with increasing deformation. The Young's Modulus is the gradient of the initial straight line portion of the stressstrain curve and has been found to be $195.32 \pm 17.85 \mathrm{~N} / \mathrm{mm}^{2}$. The yield is the point at which the initial straight line portion of force-deformation curve dips (drops off). The mean value for the deformation at peak was found to be $5.0990 \pm 0.0974 \mathrm{~mm}$ and it represents the distance travelled at point of yield. The energy to peak is the workdone to the point of yield and was found to be $0.1344 \pm$ $0.0185 \mathrm{~N}$. m. The force at break is the force at which maximum deformation was reached and was 
found to be $58.420 \pm 5.479 \mathrm{~N}$. The deformation at break represents the maximum deformation and was found to be $5.1241+0.0779 \mathrm{~mm}$. The energy to break is the energy at the point of maximum deflection and was obtained to be $0.1708+0.0184 \mathrm{~N}$.m.

In comparison with other oil bearing crops, Manuwa and Muhammad (2010) obtained maximum values of $588.55 \mathrm{~N}, 8.822 \mathrm{~mm}$ and $1.9999 \mathrm{~N} . \mathrm{m}$ for small size kernel and $940.61 \mathrm{~N}, 10.086 \mathrm{~mm}$ and $2.8946 \mathrm{~N}$.m for large size kernel; for the applied force, deformation and rupture energy of Shea kernel respectively. Olayanju (2002) obtained values of $8.7 \mathrm{~N}$ and $18.6 \mathrm{~N}$ for the force required to rupture and express oil from Yandev- 55 variety of Beniseeds at rupture and oil points respectively and $9.0 \mathrm{~N}$ and $20.8 \mathrm{~N}$ for the force required to rupture and express oil from E-8 variety of Beniseeds at rupture and oil points respectively. The corresponding deformations ranged between 0.123 $0.494 \mathrm{~mm}$ and $0.46-0.54 \mathrm{~mm}$ for rupture and oil point respectively. Tavakoli et al. (2009) reported values ranging from $270.66-191.09 \mathrm{~N}$ and $318.34-376.68 \mathrm{~mJ}$ for the rupture force and energy of Soybean grains respectively. Ahmadi et al. (2009) found that the rupture force on both seed length and width sections of Fennel seeds ranged from 78.68-198.93N and 186.44-600.65 N respectively. Aktas et al. (2006) determined the average crushing force for Safflower seeds to be in the range of 62.30-75.39 N. Heidarbeigi et al. (2008) obtained mean values of $143.07 \mathrm{~N}, 1.68 \mathrm{~mm}$ and 121.89 N.mm respectively for the crushing force, deformation and energy of Iranian Wild Pistachio. Izli et al. (2009) obtained rupture forces range of 11.61-14.94N, 8.17-13.21 N and 8.02$11.71 \mathrm{~N}$ for three varieties of Rapessed viz Capitol, Jetneuf and Samurai respectively. Karaj and Müller (2010) obtained maximum values of $0.96 \pm 0.25 \mathrm{~mm}, 1.11 \pm 0.30 \mathrm{~mm}$ and $0.92 \pm 0.26 \mathrm{~mm}$ for the deformation at rupture point in horizontal $(\mathrm{x})$, transversal $(\mathrm{y})$ and vertical $(\mathrm{z})$ directions respectively for a fraction size greater than 0.69 for Jatropha seeds. Bamgboye and Adebayo (2012) on Jatropha seeds obtained maximum rupture force of $113.99 \mathrm{~N}$ in the horizontal loading position and minimum of $26.83 \mathrm{~N}$ in the transverse loading position. They also obtained maximum deformation of $2.5 \mathrm{~mm}$ in the horizontal position and minimum of $0.40 \mathrm{~mm}$ in the vertical position. Bamgboye and Adejumo (2011) on Roselle seeds obtained values of 23.45-49.05N, 23.38-35.48 $\mathrm{Nmm}^{-2}$ and $0.41-0.50 \mathrm{~mm}$ for the compressive force, rupture stress and deformation respectively. They also obtained the following values of 27.0-38.15 $\mathrm{Nmm}^{-2}, 33.3-52.56 \mathrm{~N}$ and $216.03-374.11$ $\mathrm{Nmm}^{-2}$ for the yield stress, rupture force and Young's Modulus respectively. Gupta and Das (2000) found that the compressive forces required causing Sunflower kernel rupture range from $26.86 \mathrm{~N}$ $33.94 \mathrm{~N}$. They reported that the Sunflower seeds loaded in a vertical orientation absorbed more energy $\left(144.7-222.9 \mathrm{~J} / \mathrm{m}^{3}\right)$ prior to rupture than those loaded in the horizontal $\left(95.21-84.2 \mathrm{~J} / \mathrm{m}^{3}\right)$ orientation; while the Sunflower kernels loaded in a vertical orientation required less energy (18.1$\left.54.3 \mathrm{~J} / \mathrm{m}^{3}\right)$ to rupture than those loaded in the horizontal $\left(38.965 .8 \mathrm{~J} / \mathrm{m}^{3}\right)$ orientation. Overall, the mechanical properties determined give an indication of the strength of the Moringa seeds at peak, break and yield as well as the corresponding deformations. They also provide useful information about the energy and the force required to crush and expel oil from the seeds at the feed end portion of the machine as well as the deformation of the seeds. 


\section{CONCLUSION}

The mechanical properties of Moringa seeds in relation to the design of an oil expeller for the crop have been determined. The experiment was performed at an average seed moisture content of $7.31 \%$ wet basis. The average force to rupture the seed was obtained as $58.535 \mathrm{~N}$ varying from $49.9 \mathrm{~N}$ to $67.0 \mathrm{~N}$; while the average rupture energy of the seed was calculated as $0.1344 \mathrm{~N} . \mathrm{m}$ ranging from $0.1043 \mathrm{~N} . \mathrm{m}$ to $0.1708 \mathrm{~N} . \mathrm{m}$. The average deformation was $5.099 \mathrm{~mm}$ varying from $4.850 \mathrm{~mm}$ to $5.354 \mathrm{~mm}$. Maximum strain of about $85 \%$ was recorded for the Moringa seeds. These parameters would provide important and essential data for the efficient design of the oil expeller.

\section{REFERENCES}

Ahmadi, H., Mollazade, K., Khorshidi, J., Mohtasebi, S.S. and A. Rajabipour (2009). Some Physical and Mechanical Properties of Fennel Seed (Foeniculum vulgare). Journal of Agricultural Science, 1 (1):66-75.

Ajibola, O.O. (2000). Adding value to the Farmer's harvest. Inaugural Lecture delivered at Obafemi Awolowo University, lle-Ife, Nigeria.

Aktas, T., I. Celen and R. Durgut (2006). Some Physical and Mechanical Properties of Safflower Seed (Carthamus tinctorius L.). Journal of Agronomy, 5(4): 613-616.

Bamgboye, A.I. and O.I. Adejumo (2011). Mechanical properties of Roselle (Hibiscus sabdariffa L) seeds. Agricultural Science Research Journal. 1(8): 178-183.

Bamgboye, A.I. and S.E. Adebayo (2012). Seed moisture dependent on Physical and Mechanical properties of Jatropha curcas. Journal of Agricultural Technology, Vol. 8(1): 13-26.

Chukwu, O. and Sunmonu, M.O. (2010). Determination of Selected Engineering Properties $0 \mathrm{f}$ Cowpea (Vigna unguiculata) related to Design of Processing Machines. International Journal of Engineering and Technology, 2 (6): 373-378.

Gupta, R.K. and S.K. Das (2000). Fracture resistance of Sunflower seed and kernel to compressive loading. Journal of Food Engineering, $46: 1-8$.

Heidarbeigi, K., Ahmadi, H., Kheiralipour, K. and A. Tabatabaeefar (2008). Some Physical and Mechanical Properties of Iranian Wild Pistachio (Pistachio mutica L.). AmericanEurasian J. Agric. \& Environ. Sci., 3 (4): 521-525. 
Izli, N., Unal, H. And M. Sincik (2009). Physical and mechanical properties of rape seed at different moisture content. Int. Agrophysics, 23, 137-145.

Karaj, S. and J. Müller (2010). Determination of Physical, Mechanical and Chemical Properties of Seeds and Kernels of Jatropha curcas L. Ind. Crops Prod. Doi:10.1016/j.indcrop.2010.04.001.

Manuwa, S. I. and Muhammad, H. A. (2010). Moisture Content and Compression Axis Effects on Mechanical Properties of Shea Kernels. Journal of Food Technology, 8(3), 89-94.

Mohsenin, N. N. (1970). Physical Properties of Plant and Animal Materials. 1st edition; Gordon and Breach Science Publishers: New York.

Olajide, J.O. (2000). Process Optimization and Modelling of Oil Expression from Groudnut and Sheanut Kernels. Unpublished. Ph.D Thesis, Department of Agricultural Engineering, University of Ibadan, Ibadan, Nigeria.

Olayanju, T. M. A. (2002). Design, Fabrication and Evaluation of a Beniseed (Sesanum indicum L.) Oil Expeller. Unpublished. Ph.D Thesis, Department of Agricultural Engineering, University of Ibadan, Ibadan, Nigeria.

Ozumba I.C. and S.I. Obiakor (2011). Fracture resistance of palm kernel seed to compressive loading. Journal of Stored Products and Postharvest Research, 2(13):248253.

Tavakoli H., Rajabipour, A. and Mohtasebi, S. S. (2010). "Moisture-Dependent Some Engineering Properties of Soybean Grains". Agricultural Engineering International: The CIGR E journal. Manuscript 1110. Vol XI. February, 2009. 